\title{
PENGARUH MOTIVASI BELAJAR DAN STRATEGI BELAJAR SISWA TERHADAP HASIL BELAJAR EKONOMI UNTUK KELAS XI SMAN KABUPATEN TEBO TAHUN PELAJARAN 2019/2020
}

\author{
SIGUMANTAR \\ SMA Negeri 6 Kabupaten Tebo Provinsi Jambi \\ Email : sibumantar.8.@gmail.com
}

\begin{abstract}
ABSTRAK
Penelitian ini bertujuan untuk mengetahui 1) pengaruh motivasi terhadap hasil belajar, 2) pengaruh strategi belajar terhadap hasil belajar, dan 3) pengaruh motivasi dan strategi belajar terhadap hasil belajar. Populasi dalam penelitian ini adalah siswa kelas XI SMA kelas XI IPS Kabupaten Tebo sebanyak 379 siswa. Sampel diambil dengan menggunakan teknik simple random sampling yang menghasilkan 195 siswa. Pengumpulan data dilakukan dengan menggunakan kuesioner. Data dianalisis dengan menggunakan analisis regresi linier berganda. Hasil penelitian menunjukkan bahwa uji parsial (uji t) menunjukkan adanya pengaruh signifikan motivasi terhadap hasil belajar siswa dan pengaruh signifikan strategi belajar terhadap hasil belajar. Berdasarkan uji $\mathrm{F}$ disimpulkan bahwa motivasi dan strategi belajar secara simultan berpengaruh terhadap hasil belajar siswa. (1) Peningkatan motivasi belajar berdampak nyata pada peningkatan hasil belajar, dan besarnya pengaruh motivasi belajar terhadap hasil belajar adalah sebesar 16\% . (2) Peningkatan strategi belajar berdampak nyata pada peningkatan hasil belajar, dan besarnya pengaruh strategi belajar terhadap hasil belajar adalah sebesar 8,8\%. Strategi belajar yang dipakai dalam pelajaran ekonomi adalah strategi belajar Visual yaitu sebesar 72,8\%. (3) Motivasi belajar dan strategi belajar secara simultan berpengaruh signifikan terhadap hasil belajar dan besarnya pengaruh motivasi belajar dan strategi belajar terhadap hasil belajar adalah $28,2 \%$ sedangkan sisanya $71,8 \%$ dipengaruhi oleh faktor-faktor lain selain variabel motivasi belajar dan strategi belajar.
\end{abstract}

Kata Kunci: motivasi belajar, strategi belajar, hasil belajar ekonomi.

\section{PENDAHULUAN}

Pendidikan adalah suatu usaha atau kegiatan yang dijalankan dengan sengaja, teratur dan terencana dengan maksud mengubah atau mengembangkan perilaku yang diinginkan (Syaidah, dkk, 2018). Sekolah sebagai lembaga pendidikan formal merupakan sarana dalam rangka pencapaian tujuan pendidikan, seperti yang tertuang dalam Undang-Undang No.20 Tahun 2003 tentang tujuan Pendidikan Nasional Bab II Pasal 3. Dengan adanya undang-undang tersebut, maka salah satu tugas pokok sekolah adalah menyiapkan siswa agar dapat mencapai perkembangannya secara optimal. Seorang siswa dikatakan telah mencapai perkembanganya secara optimal apabila siswa dapat memperoleh pendidikan dan pretasi belajar yang sesuai dengan bakat, kemampuan dan minat yang dimilikinya (Sugiasih, 2016).

Upaya menciptakan manusia yang berkualitas dan berhasil tinggi, maka siswa harus memiliki hasil belajar yang baik. Hasil belajar merupakan tolak ukur yang telah dicapai siswa setelah melakukan perbuatan belajar selama waktu yang telah ditentukan bersama. Fenomena yang terjadi di SMA se-kabupaten Tebo hasil belajar yang diraih siswa mata pelajaran ekonomi kelas XI rerata 72,34 masih rendah dibawah Kriteria Ketuntatasan Minimum (KKM) yang ditetapkan masing-masing sekolah.

Berdasarkan beberapa penelitian terdahulu, terdapat beberapa faktor yang dapat mempengaruhi hasil belajar siswa diantaranya motivasi, dan strategi belajar. Kedua faktor ini menjadi penting untuk diteliti kembali karena dalam penelitian terdahulu, terbukti kedua faktor tersebut signifikan mempengaruhi hasil belajar. Berdasarkan kondisi yang berbeda dengan penelitian terdahulu maka dilakukan penelitian di SMA Negeri di Kabupaten Tebo untuk menjawab permasalahan tentang adakah pengaruh motivasi, strategi belajar terhadap hasil belajar siswa. 
Hasil belajar adalah sesuatu perubahan yang terjadi pada diri siswa setelah dilakukannya proses belajar. Senada dengan pernyataan Sobri, dkk (2014) hasil belajar merupakan segala perilaku yang dimiliki siswa sebagai akibat dari proses belajar yang ditempuhnya, meliputi semua akibat dari proses belajar yang berlangsung di sekolah atau di luar sekolah yang bersifat kognitif, afektif, maupun psikomotorik baik yang di sengaja ataupun yang tidak disengaja. Bungsu, dkk (2019) mengatakan hasil belajar sebagai nilai yang merupakan bentuk perumusan akhir yang diberikan oleh guru terkait dengan kemajuan atau hasil belajar siswa selama waktu tertentu.

Salah satu faktor yang berpengaruh terhadap hasil belajar siswa yaitu motivasi belajar. Menurut Suprihatin (2015) motivasi adalah daya upaya yang mendorong seseorang untuk melakukan sesuatu atau daya penggerak dari subyek untuk melakukan suatu perbuatan dalam suatu tujuan. Lebih lanjut menurut Sulfemi (2019) motivasi belajar dipandang sebagai dorongan mental yang menggerakkan dan mengarahkan perilaku manusia, termasuk perilaku belajar. Dalam motivasi terkandung adanya keinginan yang mengaktifkan, menggerakkan, menyalurkan, dan mengarahkan sikap dan perilaku individu belajar. Motivasi belajar juga dapat diartikan sebagai perubahan energy dalam diri seseorang itu berbentuk aktivitas nyata berupa kegiatan fisik. Sedangkan menurut Idzhar (2016) motivasi dan belajar merupakan dua hal yang saling mempengaruhi. Belajar adalah perubahan tingkah laku secara relative permanen dan secara potensial terjadi sebagai hasil dari praktek atau penguatan yang dilandasi tujuan untuk mencapai tujuan tertentu.

Faktor-faktor yang mempengaruhi hasil belajar digolongkan menjadi tiga, yaitu: faktor dari dalam, faktor dari luar, dan faktor instrumen. Faktor dari dalam yaitu faktor-faktor yang dapat mempengaruhi belajar yang berasal dari siswa yang sedang belajar (Sutrisno, dkk, 2016). Faktor-faktor ini diantaranya adalah: (a) minat individu merupakan ketertarikan individu terhadap sesuatu. Minat belajar sisw a yang tinggi menyebabkan belajar siswa lebih mudah dan cepat (b) motivasi belajar antara siswa yang satu dengan siswa lainnya tidaklah sama. Motivasi belajar dipengaruhi oleh beberapa faktor, antara lain: cita-cita siswa, kemampuan belajar siswa, kondisi siswa, kondisi lingkungan, unsur-unsur dinamis dalam belajar, dan upaya guru membelajarkan siswa (Hendrayana, 2014).

Faktor dari luar yaitu faktor-faktor yang berasal dari luar siswa yang mempengaruhi proses dan hasil belajar. Faktor-faktor ini di antaranya adalah lingkungan sosial. Yang dimaksud dengan lingkungan sosial di sini yaitu manusia atau sesama manusia, baik manusia itu hadir ataupun tidak langsung hadir. Kehadiran orang lain pada waktu sedang belajar, sering mengganggu aktivitas belajar. Salah satu dari lingkungan sosial tersebut yaitu lingkungan siswa di sekolah yang terdiri dari teman sebaya, teman lain kelas, guru, kepala sekolah serta karyawan lainnya yang dapat juga mempengaruhi proses dan hasil belajar individu (Hapnita, 2018).

Faktor instrumen yaitu faktor yang berhubungan dengan perangkat pembelajaran seperti kurikulum, struktur program, sarana dan prasarana pembelajaran (media pembelajaran), serta guru sebagai perancang pembelajaran. Dalam penggunaan perangkat pembelajaran tersebut harus dirancang oleh guru sesuai dengan hasil yang diharapkan. Berdasarkan hal di atas fakto $r$ yang mempengaruhi proses dan hasil belajar siswa baik itu faktor dari dalam, luar, maupun instrumen yang paling utama adalah minat, motivasi, dan guru (Nurmala, dkk, 2014).

Dalam proses belajar, motivasi sangat diperlukan sebab yang tidak mempunyai motivasi dalam belajar, tidak akan mungkin melakukan aktivitas belajar. Siswa dikatakan akan memiliki motivasi yang cukup kuat apabila dalam kegiatan belajar mengajar memiliki ciri-ciri tekun mengerjakan tugas, ulet dalam memecahkan masalah dan hambatan secara mandiri (Oktiani, 2017). Senada dengan itu, Masni (2017) menyebut bahwa Siswa yang telah termotivasi maka akan memiliki keinginan dan harapan untuk berhasil dan jika mengalami kegagalan maka siswa tersebut akan berusaha sekuat tenaga untuk dapat mencapai keberhasilannya yang ditunjukkan dalam hasil belajar. Dengan usaha yang tekun dan didasari motivasi yang kuat maka akan menghasilkan hasil belajar yang baik. 
Adapun Faktor lain yang berpengaruh terhadap hasil belajar yaitu strategi belajar siswa. Menurut Fatkhurrohman (2016) strategi belajar adalah cara yang dilakukan murid dalam menangkap suatu informasi dengan cara mengingat, berpikir dan memecahkan masalah, dimana berkaitan dengan pribadi seseorang yang dipengaruhi oleh pendidikan dan riwayat perkembangannya. Kusumawati (2019) mengatakan strategi belajar adalah cara yang cenderung dipilih seseorang untuk menerima informasi dari lingkungan dan memproses informasi tersebut.

Menurut Schmeck (2013) ada tiga macam strategi belajar yaitu: (1) Strategi belajar visual (2) Strategi belajar auditorial (3) Strategi belajar kinestetik. Ketiga jenis strategi belajar tersebut memiliki ciri-ciri dominan dalam melakukan suatu kegiatan. Begitu pula dengan strategi belajar siswa, terlihat adanya ciri-ciri dominan dalam suatu proses kegiatan pembelajaran, sehingga dapat mencapai hasil maksimal.

Menurut Uno dalam Gunawan (2019) Fenomena yang ada bahwa tidak semua orang punya strategi belajar yang sama. Termasuk apabila mereka bersekolah di sekolah yang sama atau bahkan duduk di kelas yang sama. Kemampuan seseorang untuk memahami dan menyerap pelajarn sudah pasti berbeda tingkatannya. Ada yang cepat, sedang, dan ada pula yang sangat lambat. Apapun cara yang dipilih, perbedaan strategi belajar itu menunjukan cara tercepat dan terbaik bagi setiap indivivu untuk bisa menyerap sebuah informasi dari luar dirinya. Kemampuan seseorang untuk mengetahui sendiri strategi belajarnya dan strategi belajar orang lain dalam lingkungannya akan meningkatkan efektifitas dalam belajar.

\section{METODE PENELITIAN}

Pendekatan dalam penelitian ini adalah pendekatan kuantitatif. Penelitian ini dirancang dengan menggunakan penelitian asosiatif. Variabel yang digunakan pada penelitian ini yaitu hasil belajar (Y), motivasi belajar (X1) dan strategi belajar (X2). Populasi dalam penelitian ini adalah siswa kelas XI IPS SMA Negeri di Kabupaten Tebo yaitu SMA Negeri 1, SMA Negeri 2, SMA Negeri 3, SMA Negeri 4, dan SMA Negeri 5 sebanyak 379 siswa. Sedangkan sampel penelitian ini yang diambil secara simple random sampling yaitu secara acak sebanyak 195 siswa. Data dikumpulkan melalui kuesioner, dan dokumentasi. Kuesioner disusun berdasarkan variable penelitian dan indikator penelitian dengan skala pengukuran instrument menggunakan skala likert. Teknik analisis menggunakan analisis uji statistik yaitu uji $\mathrm{F}$ dan Uji t. Uji $\mathrm{F}$ digunakan untuk menguji signifikansi variable motivasi, strategi belajar terhadap hasil belajar, Uji t digunakan untuk menguji signifikansi pengaruh motivasi belajar terhadap hasil belajar, dan pengaruh strategi belajar terhadap hasil belajar siswa.

\section{HASIL DAN PEMBAHASAN}

\section{Uji asumsi klasik meliputi uji linieritas, normalitas, multikolinearitas, dan Heteroskedastisitas.}

Uji Linieritas dapat dilihat dari nilai $F$ (Deviation from linearity). Nilai $F$ yang dihasilkan X1 terhadap Y sebesar 0,667 dengan nilai signifikan lebih dari 5\% yaitu sebesar 0,911. Karena tingkat signifikan yang dihasilkan melebihi 5\% maka hubungan antara mptivasi belajar (X1) dengan hasil belajar (Y) adalah linier. Sedangkan uji linieritas untuk X2 dengan Y nilai $\mathrm{F}$ yang dihasilkan sebesar 0,996 dengan nilai signifikan lebih dari 5\% yaitu sebesar 0,487. Karena tingkat signifikan yang dihasilkan melebihi 5\% maka hubungan antara strategi belajar (X2) dengan hasil belajar (Y) adalah linier.

Uji Normalitas menggunakan Uji Kolmogorov Smirnov dengan bantuan SPSS 17.0 for Windows dihasilkan Asymp. Sig > 0,05. Tingkat signifikan yang dihasilkan lebih dari 5\%, dengan demikian asumsi normalitas data terpenuhi.

Uji Multikolinearitas, dilakukan dengan bantuan SPSS 17.0 for Windows ditunjukkan oleh tabel coefficient dengan mengamati kolom tolerance dan kolom VIF. Didapatkan nilai tolerance kedua variable $>0,1$ dan nilai VIF kedua variable $<10$. Dengan demikian tidak ada multikolinearitas antara variable bebas dalam model regresi. 
Uji Heteroskedastisitas menggunakan uji Rank Spearman didapat signifikansi untuk X1 $=0,781>0,05$, untuk X2 $=0,419>0,05$. Hal ini dapat dikatakan bahwa antara variabel bebas dengan residual tidak terjadi heteroskedastisitas.

Model regresi yang yang diperoleh berdasarkan hasil penelitian, dapat dituliskan dalam bentuk persamaan regresi adalah sebagai berikut: $\mathrm{Y}=10,475+10,189 \mathrm{X} 1+6,496 \mathrm{X} 2$. Dari persamaan di atas, kedua variable bebas memiliki koefisien regresi dengan arah positif. Hal ini berarti bahwa semakin tinggi motivasi dan strategi belajar maka hasil belajar akan naik. Hasil Uji F berdasarkan uji ANOVA atau uji statistik F, model menunjukkan nilai Fhitung $=37,613$ dengan nilai signifikansi $\mathrm{p}=0,000$ lebih kecil dari 5\%. Hal ini berarti bahwa motivasi belajar dan strategi belajar secara signifikan mempengaruhi hasil belajar.

Besarnya pengaruh motivasi belajar dan strategi belajar secara simultan terhadap hasil belajar dapat dilihat dari koefisien determinasi (R-square). Berdasarkan hasil uji F dihasilkan koefisien korelasi sebesar 0,531 berarti $28,2 \%$ hasil belajar dipengaruhi oleh motivasi belajar dan strategi belajar. Sedangkan $71,8 \%$ dipengaruhi oleh variable lain yaitu diantaranya intelegensi, lingkungan belajar dan sarana prasarana.

Selanjutnya Uji parsial menunjukkan semua variable pengaruhnya signifikan. Uji parsial untuk variable motivasi belajar (X1) nilai t hitung sebesar 6,040 dengan tingkat signifikansi sebesar 5\% yaitu 0,000, variable strategi belajar (X2) nilai t hitung 4,300 dengan tingkat signifikansi $5 \%$ yaitu 0,000 . Dengan demikian variable motivasi (x1) dan strategi belajar (X2) signifikan pengaruhnya terhadap hasil belajar.

Besarnya pengaruh motivasi dan strategi belajar terhadap hasil belajar siswa dapat dilihat dari nilai r2parsial pada variabel motivasi belajar (X1) sebesar 0,160 menunjukkan bahwa motivasi belajar (X1) secara parsial berpengaruh terhadap hasil belajar (Y) sebesar 16\%. Sedangkan nilai r2parsial pada variabel strategi belajar (X2) sebesar 0,088 menunjukkan bahwa strategi belajar (X2) secara parsial berpengaruh terhadap hasil belajar (Y) sebesar 8,8\%.

Berdasarkan hasil pengolah data maka dapat disimpulkan hasil uji hipotesis pada gambar berikut:

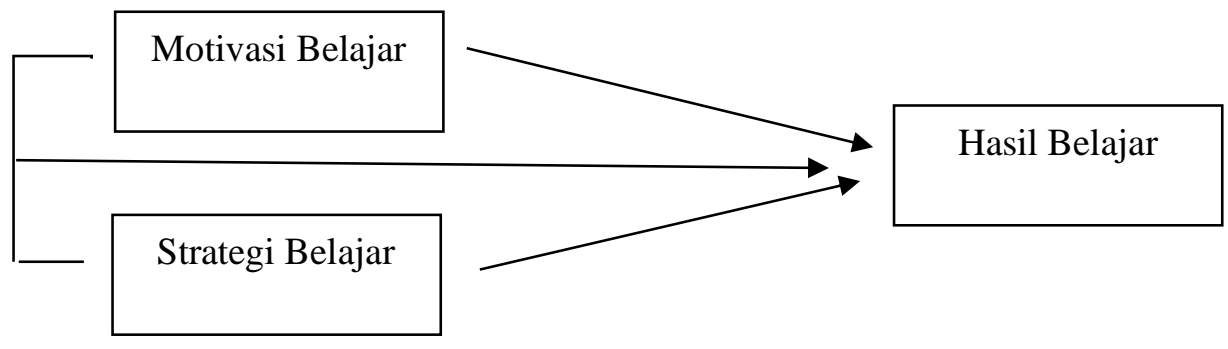

Gambar 1. Hasil Uji Hipotesis

Hasil penelitian menunjukkan bahwa secara simultan motivasi dan strategi belajar menunjukkan bahwa ada pengaruh secara signifikan terhadap hasil belajar. Implikasi dari temuan tersebut adalah semakin tinggi motivasi dan strategi belajar maka semakin tinggi hasil belajar. Sebaliknya semakin rendah motivasi dan strategi belajar maka semakin rendah hasil belajar. Hal ini sesuai dengan penelitian-penelitian sebelumnya yang dilakukan oleh Indarto (2012). Hasil belajar siswa kelas XI IPS SMA Negeri di Kabupaten Tebo berdasarkan tabulasi jawaban responden sebesar 61,03\% ini termasuk cukup bagus. Artinya motivasi belajar siswa di tingkat SMA Negeri di Kabupaten Tebo memiliki hasrat dan keinginan berhasil, harapan dan cita-cita masa depan, dorongan dan kebutuhan belajar, penghargaan dalam belajar, dan lingkungan belajar yang kondusif. Sedangkan strategi belajar yang mereka gunakan dalam pembelajaran ekonomi adalah strategi belajar visual. Karakter siswa dengan strategi belajar visual cenderung lebih cepat menyerap informasi dengan melihat bagaimana guru menerangkan didepan kelas baik dengan alat bantu, tu lisan, data maupun gambar.

Hasil penelitian menunjukkan bahwa secara parsial motivasi belajar berpengaruh signifikan terhadap hasil belajar siswa SMA di Kabupaten Tebo. Implikasi dari penelitian ini 
adalah semakin tinggi motivasi belajar maka akan dapat meningkatkan hasil belajar siswa. Temuan tersebut didukung dari data responden tentang motivasi belajar siswa SMA di Kabupaten Tebo, berdasarkan tabulasi jawaban responden sebesar 83,41\% memiliki motivasi yang cukup tinggi. Hal ini berarti siswa SMA di Kabupaten Tebo dalam proses pembelajaran memiliki hasrat dan kinginan yang kuat untuk belajar, dorongan dan kesadaran akan kebutuhan belajar, harapan dan cita-cita masa depan, serta didukung dengan lingkungan belajar yang kondusif. Hasil penelitian ini sependapat dengan Hamdu dan Lisa (2011). Menurut Hamdu dan Lisa mengatakan bahwa motivasi belajar berpengaruh terhadap hasil belajar IPA di Sekolah Dasar. Hal ini berarti motivasi mempunyai peran yang sangat penting dalam pembelajaran baik itu di jenjang Sekolah Dasar sampai jenjang Sekolah Menengah Atas, siswa memiliki motivasi dalam belajar, maka hasil belajarnya pun akan baik. Sebaliknya jika siswa memiliki kebiasaan yang buruk dalam belajar, maka hasil belajarnya pun akan rendah.

Berdasarkan hasil tabulasi jawaban pada masing-masing motivasi belajar dapat disimpulkan bahwa nilai tertinggi terdapat penghargaan dalam belajar yang menyatakan bahwa siswa akan memiliki motivasi yang tinggi jika dalam belajar siswa diberikan reward atau penghargaan. Peran guru dalam proses pembelajaran harus lebih memperhatikan siswa. Guru dalam memberikan reward seperti memberikan pujian, angka, dan hadiah. Sedangkan nilai terendah jawaban pada tabulasi motivasi belajar terdapat dorongan dan kebutuhan belajar yaitu siswa dalam belajar dorongan untuk belajar kurang, ini disebabkkan siswa dalam belajar menganggap bahwa belajar itu hanya sebagai kewajiban bukan sebagai kebutuhan. Sehingga siswa belajar hanya dalam waktu-waktu tertentu saja seperti ulangan harian ulangan tengah semester dengan demikian belajar siswa tidak dapat maksimal.

Secara teori seperti yang dikemukakan oleh Djamarah (2002:41) mengatakan bahwa kesalahan dalam memberikan motivasi akan berakibat merugikan hasil belajar siswa. Hal ini berarti siswa harus memiliki motivasi belajar yang tinggi untuk dapat meningkatkan presatasi belajar.

Hasil penelitian menunjukkan bahwa secara parsial strategi belajar berpengaruh signifikan terhadap hasil belajar siswa SMA di Kabupaten Tebo. Implikasi dari penelitian ini adalah semakin baik strategi belajar maka akan dapat meningkatkan hasil belajar siswa. Hasil penelitian diketahui bahwa siswa SMA Negeri di Kabupaten Tebo yang memiliki strategi belajar visual 72,8\%, strategi belajar auditorial 8,2\%, dan strategi belajar kinestetik 19\%. Dengan demikian untuk matapelajaran ekonomi siswa SMA Negeri di Kabupaten Tebo strategi belajar mereka cenderung menggunakan strategi belajar Visual. Guru matapelajaran ekonomi dalam menyampaikan materi maka strategis belajar yang dipakai dengan cara gambar, grafik, dengan menggunakan multimedia (video dan komputer) sehingga siswa dapat dengan mudah menyerap informasi yang diberikan oleh guru.

Pemakaian strategi belajar oleh individu sebenarnya merupakan sarana untuk memfasilitasi agar belajar dapat mencapai tujuanya, yaitu perubahan, maka setiap individu mempunyai cara tersendiri yang dipilih sesuai dengan dirinya, informasi dari luar dirinya dapat diserap, diolah dan diorganisirkan dengan baik. Sehingga perbedaan strategi belajar yang dipilih individu menunjukkan cara tercepat dan terbaik bagi setiap individu bisa menyerap sebuah informasi dari luar dirinya. Dan pada akhirnya dapat mencapai hasil belajar yang optimal. Dengan demikian maka dapat disimpulkan bahwa dengan strategi belajar apapun, jika kita sudah paham betul dengan diri masing-masing individu maka akan dengan mudah untuk menyerap informasi yang ada.

Penelitian ini juga menunjukkan bahwa tidak ada perbedaan nilai rata-rata pencapaian hasil belajar ekonomi berdasarkan strategi belajar. Dengan nilai rata-rata 73,52 pada siswa SMA Negeri di Kabupaten Tebo memiliki strategi belajar visual, nilai rata-rata UAS 76,47 pada siswa yang memiliki strategi belajar auditorial dan nilai rata-rata 75,48 pada siswa dengan strategi belajar kinestetik. Sehingga dapat disimpulkan bahwa tidak ada strategi belajar siswa tertentu yang mendominasi tingkat hasil belajar ekonomi. 
Hasil penelitian ini sependapat dengan penelitian Peniati (2012) dan Akhir (2017) yang menyimpulkan bahwa strategi belajar secara signifikan berpengaruh terhadap hasil belajar siswa. Hal ini didukung oleh pendapat Miskawati (2019) menyebutkan bahwa mengetahui strategi belajar yang berbeda telah membantu para siswa, dengan demikian akan memberikan persepsi yang positif bagi siswa tentang cara mengajaar guru mengajar.

Berdasarkan hasil pengujian hipotesis dan hasil penelitian terdahulu tidak ditemukan hasil penelitian yang bertolak belakang dengan hasil penelitian ini. Hasil penelitian terdahulu semuannya memberikan kesimpulan yang sama yaitu motivasi belajar dan strategi belajar berpengaruh signifikan terhadap hasil belajar siswa.

\section{KESIMPULAN}

Berdasarkan analisis regresi linier berganda, maka kesimpulan yang dapat diambil adalah sebagai berikut: (1) Peningkatan motivasi belajar berdampak nyata pada peningkatan hasil belajar, dan besarnya pengaruh motivasi belajar terhadap hasil belajar adalah sebesar $16 \%$. (2) Peningkatan strategi belajar berdampak nyata pada peningkatan hasil belajar, dan besarnya pengaruh strategi belajar terhadap hasil belajar adalah sebesar 8,8\%. Strategi belajar yang dipakai dalam pelajaran ekonomi adalah strategi belajar Visual yaitu sebesar $72,8 \%$. (3) Motivasi belajar dan strategi belajar secara simultan berpengaruh signifikan terhadap hasil belajar dan besarnya pengaruh motivasi belajar dan strategi belajar terhadap hasil belajar adalah $28,2 \%$ sedangkan sisanya $71,8 \%$ dipengaruhi oleh faktor-faktor lain selain variabel motivasi belajar dan strategi belajar.

\section{DAFTAR PUSTAKA}

Akhir, M. (2017). Penerapan strategi belajar reciprocal teaching terhadap kemampuan membaca pada siswa SD. Indonesian Journal of Primary Education, 1(2), 30-38.

Fatkhurrokhman, M. (2016). Strategi belajar siswa pada kegiatan praktik kerja industri dalam memperoleh kompetensi. VOLT: Jurnal Ilmiah Pendidikan Teknik Elektro, 1(1), 4758.

Gunawan, R. G., \& Putra, A. (2019). Pengaruh strategi belajar aktif sortir kartu terhadap kemampuan pemecahan masalah matematis. Jurnal Cendekia: Jurnal Pendidikan Matematika, 3(2), 362-370.

Hapnita, W. (2018). Faktor internal dan eksternal yang dominan mempengaruhi hasil belajar menggambar dengan perangkat lunak siswa kelas XI teknik gambar bangunan SMK N 1 Padang tahun 2016/2017. CIVED (Journal of Civil Engineering and Vocational Education), 5(1).

Hendrayana, A. S. (2014). Motivasi Belajar, Kemandirian Belajar dan Hasil Belajar Mahasiswa Beasiswa BIDIKMISI DI UPBJJ UT Bandung. Jurnal Pendidikan Terbuka dan Jarak Jauh, 15(2), 81-87.

Idzhar, A. (2016). Peranan guru dalam meningkatkan motivasi belajar siswa. Jurnal office, 2(2), 221-228.

Kusumawati, N., \& Maruti, E. S. (2019). Strategi belajar mengajar di sekolah dasar. Cv. Ae Media Grafika.

Masni, H. (2017). Strategi Meningkatkan Motivasi Belajar Mahasiswa. Jurnal Ilmiah Dikdaya, 5(1), 34-45.

Miskawati, M. (2019). Upaya Meningkatkan Kreativitas Anak Dalam Pembelajaran Seni Tari Melalui Strategi Belajar Sambil Bermain di TK Islam Sa'adatul Khidmah Tahun Pelajaran 2016/2017. Jurnal Ilmiah Dikdaya, 9(1), 45-54.

Nurmala, D. A., Tripalupi, L. E., \& Suharsono, N. (2014). Pengaruh motivasi belajar dan aktivitas belajar terhadap hasil belajar akuntansi. Jurnal Pendidikan Ekonomi Undiksha, 4(1).

Peniati, E. (2012). Pengembangan modul mata kuliah strategi belajar mengajar IPA berbasis hasil penelitian pembelajaran. Jurnal Pendidikan IPA Indonesia, 1(1). 
Schmeck, R. R. (Ed.). (2013). Learning strategies and learning styles. Springer Science \& Business Media.

Sobri, M., \& Moerdiyanto, M. (2014). Pengaruh kedisiplinan dan kemandirian belajar terhadap hasil belajar ekonomi Madrasah Aliyah di Kecamatan Praya. Harmoni Sosial: Jurnal Pendidikan IPS, 1(1).

Sugiasih, P., Tripalupi, L. E., \& Meitriana, M. A. (2016). Pengaruh peran guru sebagai motivator terhadap motivasi belajar Ekonomi siswa SMA Se-kecamatan Seririt tahun pelajaran 2014/2015. Jurnal Pendidikan Ekonomi Undiksha, 5(1).

Sulfemi, W. B. (2019). Hubungan Motivasi Belajar Dengan Hasil Belajar IPS Di SMP Kabupaten Bogor.

Suprihatin, S. (2015). Upaya guru dalam meningkatkan motivasi belajar siswa. Jurnal Pendidikan Ekonomi UM Metro, 3(1), 73-82.

Sutrisno, V. L. P., \& Siswanto, B. T. (2016). Faktor-faktor yang mempengaruhi hasil belajar siswa pada pembelajaran praktik kelistrikan otomotif SMK di Kabupaten Yogyakarta. Jurnal pendidikan vokasi, 6(1), 111-120.

Syaidah, U., Suyadi, B., \& Ani, H. M. (2018). Pengaruh kompetensi guru terhadap hasil belajar ekonomi di SMA Negeri Rambipuji Tahun Ajaran 2017/2018. Jurnal Pendidikan Ekonomi: Jurnal Ilmiah Ilmu Pendidikan, Ilmu Ekonomi dan Ilmu Sosial, 12(2), 185191. 